\title{
Study on the vaginal smear of rats submitted to autologous ovarian transplant. Impact of remote ischemic preconditioning ${ }^{1}$
}

\author{
Estudo do esfregaço vaginal de ratas submetidas a transplante autólogo de ovário. Impacto do \\ precondicionamento isquêmico remoto
}

\author{
Luciana Lamarão Damous ${ }^{\mathrm{I}}$, Sônia Maria da Silva ${ }^{\mathrm{II}}$, Renato Antônio Migliano Lopes ${ }^{\mathrm{III}}$, Célia Regina de Souza Bezerra Sakano ${ }^{\mathrm{IV}}$, \\ Manuel de Jesus Simõesv , Edna Frasson de Souza MonterovI \\ I PhD, Surgery and Research Postgraduate Program, UNIFESP[0], Sao Paulo, Brazil. \\ ${ }^{\text {II }}$ Fellow PhD degree, Surgery and Research Postgraduate Program, UNIFESP, Sao Paulo, Brazil. \\ III Fellow PhD degree, Department of Pathology, UNIFESP, Sao Paulo, Brazil. \\ ${ }^{\text {IV }}$ MS, Citopathologist, Gynecological Division, UNIFESP, Sao Paulo, Brazil. \\ ${ }^{v}$ Associate Professor, Histology and Structural Biology Division, Department of Morphology, UNIFESP, Sao Paulo, Brazil. \\ ${ }^{V I}$ Associate Professor, Operative Technique and Experimental Surgery Division, Department of Surgery, UNIFESP, Sao Paulo, Brazil.
}

\begin{abstract}
Purpose: To evaluate the remote ischemic preconditioning (R-IPC) impact on the quality of the ovarian graft by means of vaginal smear of transplanted rats. Methods: Sixty rats were used divided in six groups: Control; Fresh transplant (TxF); Cryopreserved transplant (TxC); R-IPC; R-IPC + fresh transplant (TxF+R-IPC); R-IPC + cryopreserved transplant (TxC+R-IPC). R-IPC was performed in the common iliac artery. Autologous ovarian tissue was implanted integrally in the retro peritoneum. On the first PO day, vaginal smear collection was daily initiated. After 30 days, the PO day when the estrous cycle was re-initiated was considered for analysis as well as the estrous days and the number of estrous cycles. Results: R-IPC showed a tendency to an early estrus re-initiation ( $>0.05$ ) as well as increase the number of cycles in the fresh transplanted group while in the cryopreserved transplant the number of cycles was similar, regardless of the stimulus R-IPC ( $>>0.05)$. The animals which had undergone fresh grafts had a longer estrous period than the ones which had undergone cryopreserved grafts, with or without R-IPC $(\mathrm{p}<0.05)$. Conclusion: R-IPC promoted earlier re-initiation of ovarian activity in the PO and greater estrous frequency, with more consistent results in the fresh grafts than in the cryopreserved ones. Key words: Transplantation, Autologous. Ischemic Preconditioning. Vaginal Smears. Ovary. Rats.
\end{abstract}

\section{RESUMO}

Objetivo: Avaliar o impacto do precondicionamento isquêmico remoto (PCI-R) na qualidade do enxerto ovariano através dos esfregaços vaginais dos animais transplantados. Métodos: Foram utilizadas 60 ratas, distribuídas em seis grupos de estudo: Controle; Transplante fresco; Transplante criopreservado; PCI-R; PCI-R + Transplante fresco; PCI-R + Transplante criopreservado. O PCI-R foi realizado na artéria ilíaca comum. O tecido ovariano foi implantado íntegro no retroperiônio. No $1^{\circ}$ dia de pós-operatório (PO) foram coletados esfregaços vaginais diariamente. Após 30 dias foram considerados para análise o dia de PO de retorno do estro, assim como o número de dias em estro e de ciclos estrais. Resultados: PCI-R mostrou tendência em reinício mais precoce do cilo estral ( $>0,05)$, assim como aumento no número de cilcos estrais nos grupos com transplante fresco enquanto que no criopreservado o número de ciclos foi semelhante, independente do PCI-R $(p>0,05)$. Os animais que receberam enxertos frescos apresentaram mais dias na fase estro do que os criopreservados, com ou sem PCI-R. Conclusão: O PCI-R promoveu retorno mais precoce da atividade ovariana no PO e maior freqüência de estro, sendo os resultados mais consistentes nos enxertos frescos do que nos criopreservados.

Descritores: Transplante Autólogo. Precondicionamento Isquêmico. Esfregaço Vaginal. Ovário. Ratos.

${ }^{1}$ Research performed at the Surgery and Research Postgraduate Program, Federal University of Sao Paulo (UNIFESP), Brazil.

\section{Introduction}

A method that has been presently studied in order to preserve female reproductive function is the cryopreserved ovarian transplant either at an orthotopic or heterotopic site, due to the presence of a large number of primordial follicles potentially capable of maturing. These follicles are more resistant not only to aggression resulted from the transplant but also from the cryopreservation process, which makes this technique a very promising one ${ }^{1}$.

The transplant itself is the principal factor contributing to the loss of a considerable quantity of viable follicles and is directly related to the necessary time for the re-establishing of blood supply and consequently compromising graft survival. The longer the time course of angiogenesis, the shorter is graft survival. Thus, measures to accelerate revascularization are greatly expected by specialists $^{1,2}$. 
Many studies have shown that the phenomenon labeled ischemic preconditioning (IPC) protects organs such as the myocardium and the liver from ischemic and reperfusion lesion $(\mathrm{I} / \mathrm{R})$. During the ischemic period, oxygen free radicals are produced, causing endothelial lesion, increase in the microcirculation permeability and tissue edema, besides inflammatory response activation by means of the expression of adhesion molecules and cytokine production ${ }^{3}$.

In relation to the liver, IPC demonstrated that it offers protection against the deleterious effects of $\mathrm{I} / \mathrm{R}$, reducing aminotransferase from the oxidative stress, with consequent mitochondrial protection and better tolerance to the production of oxygen reactive species in the early phase of reperfusion. It has also been used in liver and kidney transplant ${ }^{3}$.

In rodents, the study of vaginal cytological smear is an efficient method in the evaluation of ovarian function due to the short life of the estrous cycle as well as the facility to characterize its many phases. The median duration of the estrous cycle is 4 to 5 days in $60 \%$ to $70 \%$ of the animals. Irregular cycles are characterized when phase alternation does not present a pro estrous - metaestrous - diestrous sequence or when there is permanence in the same phase for four to five days ${ }^{4}$. Some experimental studies use vaginal smear cytological analysis as an indirect and dynamic parameter of ovarian activity re-initiation, after the transplant ${ }^{5-8}$.

Although experimental models of ovarian transplant have already been well established, with high rates of reproduction and successful engraftment no matter the site, a functional loss in a short period of time occurs which has stimulated the search for strategies that may improve ovarian graft survival or its functional quality. In one of our previous studies it was reported that R-IPC for a 15 minute period caused a better early graft revascularization via VEGF (Vascular endothelial growth factor) as well as a better preservation of ovarian follicles 9 . Thus, the object of the present study is to evaluate the R-IPC impact on the quality of the ovarian graft by means of vaginal smear of transplanted female rats.

\section{Methods}

This study was submitted to the appreciation and approval of the Committee of Ethics and Research of the Federal University of Sao Paulo (UNIFESP) under protocol 1327/2006. Sixty adult virgin female Wistar EPM1 rats, two to three months old, weighing 200 to $300 \mathrm{~g}$ were used in this study. During the experiment the animals were fed water and rat food ad libitum.

The animals were divided in six study groups, according to the utilized procedure: 1) Control Group (Control): unilateral ooforectomy; 2) Group of Fresh Transplant (TxF): bilateral ooforectomy followed by unilateral fresh ovarian transplant; 3) Cryopreserved ovarian transplant Group (TxC): bilateral ooforectomy followed by unilateral cryopreserved ovarian transplant; 4) Remote ischemic preconditioning Group (R-IPC): R-IPC; 5) Remote ischemic preconditioning group + ooforectomy + fresh ovarian transplant (TxF+R-IPC): R-IPC, followed by bilateral ooforectomy and fresh ovarian transplant; 6) Remote ischemic preconditioning group + ooforectomy + cryopreserved ovarian transplant (TxC+R-IPC): R-IPC, followed by bilateral ooforectomy and cryopreserved ovarian transplant.

Fifteen days before the surgical procedures, all animals were submitted to daily vaginal smear collection, taken at the same time everyday in order to characterize the regularity of the estrous cycle. Only the animals that presented regular cycles of 4 to 5 days were used, with the characterization of the proestrous, estrous and diestrous phases. The diestrous phase was established for the ovarian transplant and the estrous phase for euthanasia.

The animals were weighed and anesthetized with an intramuscular injection of the association of ketamine $(70 \mathrm{mg} / \mathrm{kg})$ and xylazine $(10 \mathrm{mg} / \mathrm{kg})$, kept under spontaneous respiration at room temperature during the surgical intervention. All surgical procedures were performed with surgical microscope at 10x magnification. After the shaving of the animals' back and anti-sepsis with polyvinilpirrolidona- iodine a median laparotomy was performed with posterior inventory of the abdominal cavity.

After the identification of the ovaries and their pedicles, a sectioning of the medium-ovary, between ligatures was made and sutured with 8-0 nylon thread for bi-lateral ovary exeresis. The ovary to be transplanted underwent fat cleaning and washing with $0.9 \%$ physiological solution, before the transplant. After cleaning the ovary, it was immediately fixed on the retro-peritoneum, without vascular anastomosis and fixed with a simple 8-0 prolene stitch. The contra-lateral ovary was sent to routine histological processing to exclude possible previous animal pathologies.

In the animals submitted to R-IPC, this was performed by clamping the common iliac artery, immediately bellow the aorta bifurcation, with two vascular micro clamps for a 15 minute ischemia period, followed by a 15 minute reperfusion ${ }^{9}$, before the other procedures above described were performed (ooforectomy and transplant). In the group without R-IPC, the animals underwent a thirty minute observation period which corresponded to R-IPC time in order to standardize the operatory timing. The suturing of the wall was performed in two planes: Peritoneum-aponeurotic and skin, both sutured with 5-0 monofilament nylon thread.

In the groups submitted to cryopreserved ovarian transplant, after bilateral ooforectomy, cryopreservation was performed according to the following protocol: the fresh ovary was immediately frozen in a slow cooling freezer. The ovaries were placed in $1,2 \mathrm{~mL}$ cryotubes with $1 \mathrm{~mL}$ dimethylsufoxide (DMSO) $1,4 \mathrm{M}$ as cryoprotector in TL-HEPES medium and maintained at room temperature for 5 minutes. The cryotubes were sealed by twisting their caps, placed in a temperature programmed freezer (CL-8800, Cryogenesis software, Freezer Control) and frozen at $1^{\circ} \mathrm{C} /$ minute of $25^{\circ} \mathrm{C}$, to $10^{\circ} \mathrm{C}$, and then $0,5^{\circ} \mathrm{C} /$ minute to $-7^{\circ} \mathrm{C}$, and finally maintained at $-7^{\circ} \mathrm{C}$ for 5 minutes. The tissue was frozen at $-55^{\circ} \mathrm{C}$ at temperatures of $0,5^{\circ} \mathrm{C} /$ minute, placed in liquid nitrogen at $-196^{\circ} \mathrm{C}$ and maintained for 24 hours ${ }^{10}$.

For defrosting, the cryotube was maintained at room temperature until the ice melted (15 to 20 minutes) and, next, the tissue was transferred to $5 \mathrm{ml}$ of TL-HEPES $5 \mathrm{ml}$ at room temperature for ten minutes and then gently shaken to start tissue DMSO efflux. The tissue was maintained in TL-HEPES at $37^{\circ}$ until the transplant ${ }^{10}$. A second laparotomy was performed in the corresponding groups for the exeresis of the remaining ovary and transplantation of the cryopreserved one, utilizing the same technique previously described.

On the first PO day, vaginal smear collection was daily reinitiated, always at the same time of the day, for 30 days. Vaginal smear collection was performed (the animals were kept immobile) with a swab imbibed in physiological solution on a standard glass slide and immediately fixed in absolute alcohol for posterior 
staining using Shorr-Harris technique. The glass slides were analyzed on light microscope, 10x and 40x magnified. The following phases of the estrous cycle were considered, according to the proportion of observed cells in the smears: 1) Proestrous phase: predominance of epithelial nuclear cells; 2) Estrous phase: predominance of keratinized anucleate cells; 3) Diestrous phase: the same proportion of leukocytes and nuclear epithelial and keratinized cells ${ }^{4}$.

After thirty days of collection, the PO day when the estrous cycle was re-initiated was considered for analysis as well as the estrous days and the number of estrous cycles.

For the analysis of the results, Variance Analysis (ANOVA) was used, considering the nature of the studied variables and 0.05 or $5 \%$ was the established rejection level of the nullity hypothesis. Significant values were marked with an asterisk.

\section{Results}

All the animals' smears showed estrogenic activity in the post operatory period (100\% frequency), except one animal of TxC+R-IPC group (83.3\% frequency).

The animals submitted to ovarian transplant presented later estrous re-initiation than those submitted to ooforectomy, with or without R-IPC (TxC, TxF, TxC+R-IPC, TxF+ R-IPC vs Control $p<0.001)$. Among the transplanted groups without R-IPC, TxF presented an earlier estrous re-initiation than TxC (13 vs 20 days) $(p>0,05)$. When the impact of R-IPC was analyzed, there was a tendency to an early estrous re-initiation in TxF+R-IPC and TxC+R-IPC ( $>>0.05)$. R-IPC presented a later estrous re-initiation in relation to Control ( 6 days vs 4 days $p>0.05$ ) (Figure 1).

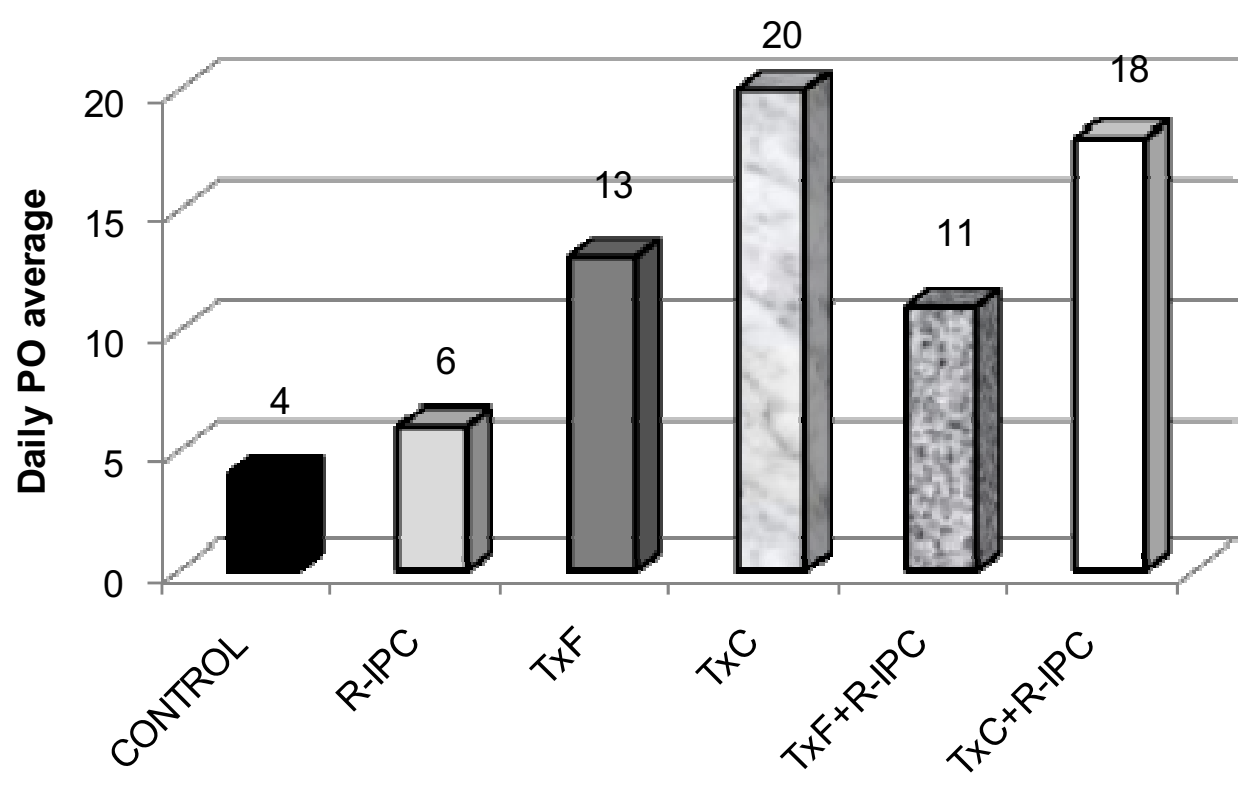

FIGURE 1 - Days of estrous re-initiation, expressed in average per group. $\mathrm{p}<0.05$

CONTROL $<$ TxF+ R-IPC, TxC+R-IPC, TxF, TxC.

R-IPC $<$ TxC+R-IPC, TxF, TxC.

TxF $>$ R-IPC, CONTROL.

TxC $>$ TxF+R-IPC, R-IPC, CONTROL.

TxF+R-IPC $<$ TxC $>$ CONTROL.

TxC+R-IPC $>$ CONTROL, R-IPC.

All transplanted animals presented an increase in the number of days of the estrum period when compared to animals that had undergone ooforectomy (Control and R-IPC) $(\mathrm{p}<0.05$ 11 to 15 days, 16 and 20 days and 21 to 25 days). The animals which had undergone fresh grafts had a longer estrum period than the ones which had undergone cryopreserved grafts, with or without R-IPC ( $<<0.0511$ to 15 days ans 16 to 20 days) (Figure 2).

In the transplanted groups, besides the increase in the days of the estrous period, there was less regularity in the estrous cycle, with predominant alternation between the estrous and diestrous phases. 


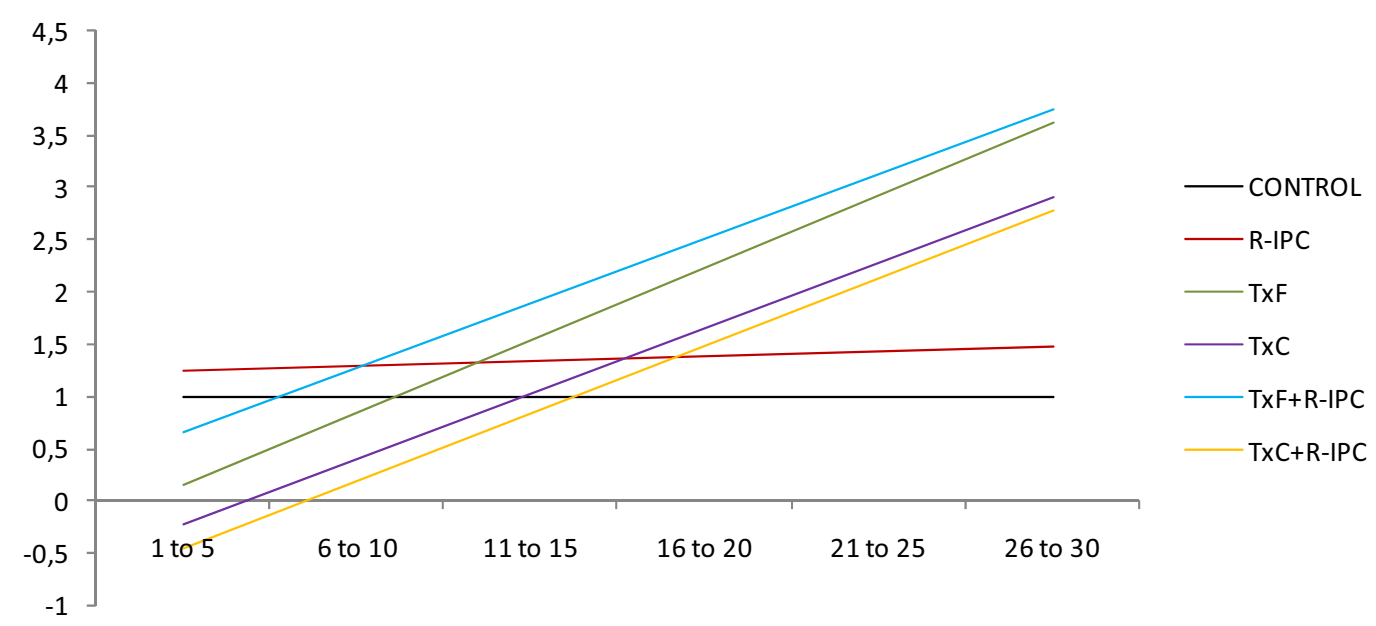

FIGURE 2 - Tendency lines of the average number of estrous days for each group separately, at each 5 day intervals, totalizing 30 post-operatory days. Zero ( 0 ) day corresponds to the surgery day. $p<0.05$

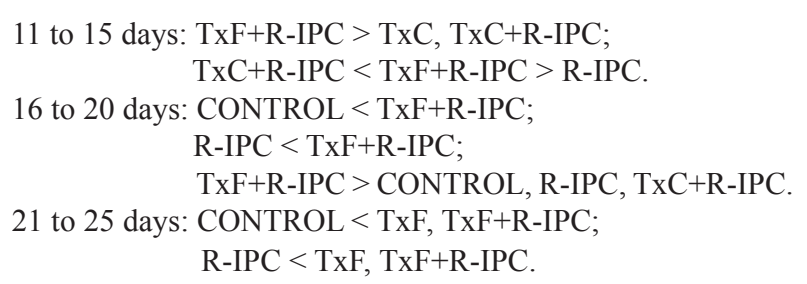

When analyzing the number of estrous cycles during the 30 post-operatory days, R-IPC showed a tendency to increase the number of cycles in the fresh transplanted group while in the cryopreserved transplant the number of cycles was similar, regardless of the stimulus R-IPC ( $>0.05)$ (Figure 3$)$.

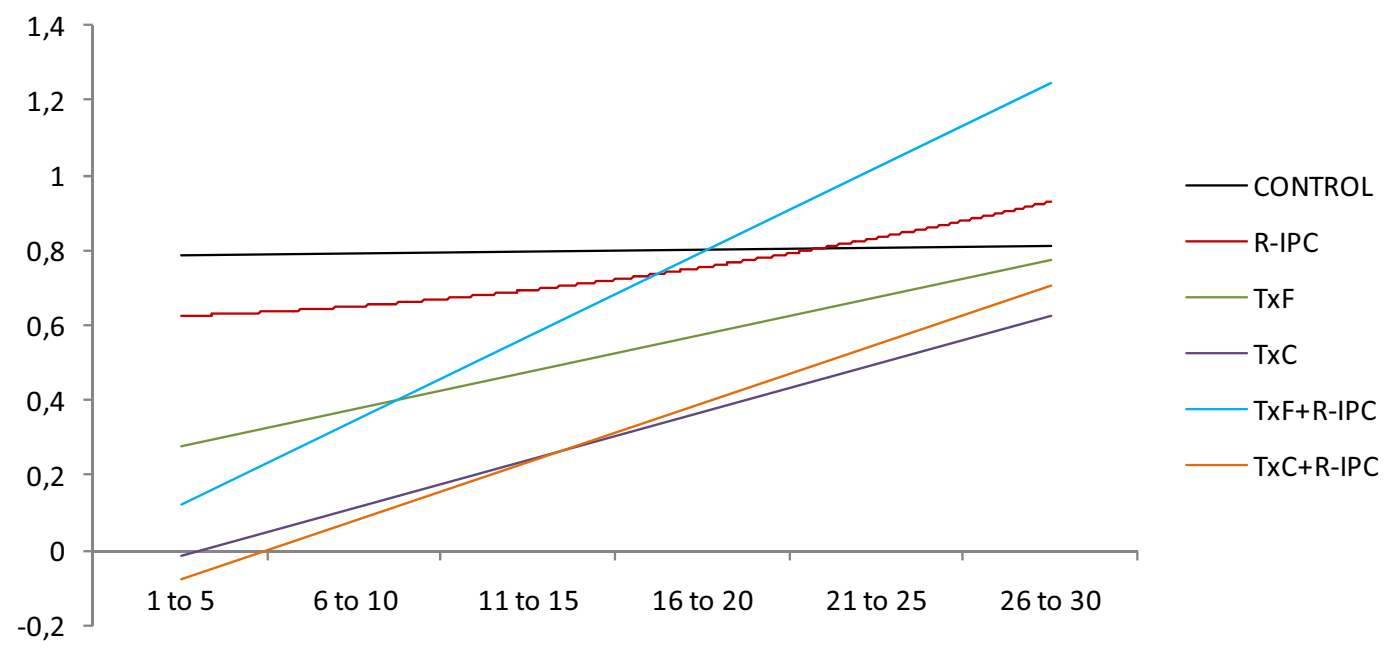

FIGURE 3 - Tendency lines of the average number of estrous cycles, for each group separately, at each five day interval, totaling $30 \mathrm{PO}$ days. Zero (0) day corresponds to surgery day. $\mathrm{p}<0.05$ :

11 to 15 days: TxC+R-IPC $<$ CONTROL, R-IPC 


\section{Discussion}

R-IPC caused an earlier re-initiation of the ovarian activity and increased the number of cycles in the fresh graft while in the cryopreserved graft there was no interference. Once the ovarian function was re-initiated, there was an increase in estrous frequency in all transplanted animals, with estrous cycle irregularity where an alternation between the estrous and diestrous phases with the predomination of the estrous phase was noted. This increase may be due to a compensating effect after $\mathrm{I} / \mathrm{R}$ aggression during the transplant when growth factors are produced to establish graft angiogenesis. Once this new vascular web is established, this may stimulate the graft to re-initiate its function which justifies the findings in the vaginal smears. As ovulation lasts from the beginning of the pro-estrous phase until the end of the estrous phase $^{4}$, the lack of characterization of the first phase in this study may be due to graft hyper-stimulation as an adaptation to the new implant site, leading to the shortening of the pro-estrous phase.

This information permits us not only to corroborate the efficacy of the autologous ovarian transplant (already established in previous models) as well as to analyze the standard estrous cycle of these animals. Corleta et al. ${ }^{11}$ used the evaluation of vaginal smear and uterus weight as a parameter for the re-initiation of the ovarian function during the three weeks after the transplant. According to these authors, $88.9 \%$ of the animals presented estrogenic activity in the vaginal smear after sub-cutaneous implant, with similar frequency registered in this study $(100 \%$ in most groups).

Alberti et $a l . .^{5}$, in a ten day evaluation period between the 3rd and 6th month of heterotrophic transplant, registered inadequate ovarian function in the transplanted group, in animals that remained in diestrous or presented irregular cycles. A similar finding was reported by Gunasena et al. ${ }^{10}$ when they compared fresh and cryopreserved grafts, for, regardless of the presence of epithelial cells on the 15th PO day in both groups, the vaginal smears not always showed clear estrous cycles at the pre-operatory period.

In accordance with Nugent et al. ${ }^{2}$ who noted a temporary interruption of ovarian function after the transplant, the information in this study showed that this interruption lasted an average of 16 days in the transplanted groups, 12 days in the fresh grafts and 19 days in the cryopreserved grafts. However, this function re-initiates after the recruitment of the surviving primordial follicles. In the absence of R-IPC, fresh grafts presented better results than the cryopreserved grafts. Although cryopreservation does not significantly interfere with follicular loss after the transplant ${ }^{1,10}$, it was noted that in these groups there is a longer latent period before the re-initiation of the ovarian function in relation to fresh transplant (13 vs 20 days without R-IPC and 11vs 18 days with R-IPC).

The rate of follicular survival is $58 \%$ in fresh transplant with a decrease of 7 to $9 \%$ when it is cryopreserved, which shows that the transplant itself and not the cryopreservation process is the principal cause of follicular loss. There are reports relating that, when the cryoprotector utilized is DMSO, follicular survival is 81 to $94 \% \%^{7}$. According to Nisolle et al. $^{8}$ fibrosis rate in ovarian transplant in significantly higher in cryopreserved implant than in the fresh implant, regardless on the implantation site. This evidence may explain that, although there was no functional graft damage, the fresh graft implant presented better results, according to the parameters analyzed in the vaginal smears. Schubert et al. ${ }^{12}$ reinforce this hypothesis because, based on histological analysis, they suggest that cryopreserved tissue follicles need a longer time to mature. Similar considerations were made by Choi et al. ${ }^{13}$ that cryopreservation may delay the development of preantral follicles due to the suppression of cellular proliferation by PCNA on the granulose layer and the increase of cellular necrosis in these follicles. Although there are reports of this delay in the development, cryopreservation does not affect the ultra-structure of the ovarian tissue ${ }^{14}$.

According to Weissman et al. ${ }^{6}$, animals submitted to heterotrophic transplant in the sub-cutaneous tissue initiated their estrous cycle on the 9th PO day, and on the 14th day all the animals presented estrogenic activity on the smear, with a longer interval between the estrous phases of $7.1 \pm 1.9$ days, contrary to what has been noted in this study in which many animals presented a continuous estrous phase.

This may be due to technical differences used in both studies, as well as the different implantation site, since the peritoneal medium which is more vascularized than the subcutaneous, offers a better a stimulus to the ovarian natural medium, although these authors suggest that there is no difference between the sites in relation to re-initiation of vascularity. The average of ovarian function re-initiation was similar between the studies (average $\mathrm{TF}=13.3$ days $)^{6}$

Liu et al. ${ }^{7}$ evaluated vaginal smear cytology of animals subjected to fresh and cryopreserved transplants, during one month, from 5 to 7 times a week and noted the presence of keratinized cells in both groups as from the 11th PO day, with an estrum interval of 2.7 to 3.5 days, respectively.

This information is similar to that registered in this study in relation to greater estrous frequency after the transplant in relation to the control groups, the same way as the fresh transplant group presented a higher estrous frequency than the cryopreserved group. However, no significant difference was noted in relation to the re-initiation of the estrous cycle among the groups. In this present study, cryopreserved grafts re-initiated their estrous cycle later than the fresh implanted ones, presenting inclusively animals that remained anovulatory after the transplant (11.1\% of the sample).

When the effect of R-IPC in the fresh and cryopreserved ovarian grafts was analyzed, it was noted that both groups presented an increase in estrous frequency, more frequently noted in the fresh grafts group. Likewise, when we analyze the postoperatory day in which the ovarian activity re-initiates, group TxF+RIPC was more precocious than TxC+R-IPC (11 days vs 18 days).

The R-IPC stimulus leads to the suppression of proinflammatory genes in human leukocytes which may contribute to the R-IPC protector effect and, maybe, in other inflammatory processes ${ }^{15}$. The best results were obtained in the fresh transplant group with R-IPC, in both analyzed parameters and in the cryopeserved group, although there was not an increase in estrum days, the re-initiation of the ovarian function was more precocious in relation to the cryopreserved group without R-IPC. Due to the fact that it is no $t$ too invasive and virtually free of additional costs in other surgical applications, besides the benefic results presented in clinical studies, this procedure is prone to be more and more performed in different circumstances, always aiming at tissue protection ${ }^{15}$. 


\section{Conclusion}

R-IPC presented a benefic effect on the autologous ovarian transplant which caused earlier re-initiation of ovarian activity in the PO and greater estrous frequency, with more consistent results in the fresh grafts than in the cryopreserved ones.

\section{References}

1. Bedaiwy MA, El-Nashar SA, El Saman AM, Evers JL, Sandadi S, Desai N, Falcone T. Reproductive outcome after transplantation of ovarian tissue: a systematic review. Hum Reprod. 2008;23(12):2709-17.

2. Nugent D, Newton H, Gallivan L, Gosden RG. Protective effect of vitamin $\mathrm{E}$ on ischaemia-reperfusion injury in ovarian grafts. J Reprod Fertil.1998;114(2):341-6.

3. Ambros JT, Herrero-Fresneda I, Borau OG, Boira JM. Ischemic preconditioning in solid organ transplantation: from experimental to clinics. Transpl Int. 2007;20(3):219-29.

4. Marcondes FK, Bianchi FK, Tanno AP. Determination of the estrous cycle phases of rats: somo helpful considerations. Braz J Biol. 2002;62(4A):609-14.

5. Petroianu A, Vasconcellos LS, Leite JM, Alberti LR, Castro LPF. Gestação obtida em coelha após ooforectomia bilateral e transplante ovariano homógeno. Rev Col Bras Cir. 2003;30(4):262-7.

6. Weissman A, Gotlieb L, Colgan T, Jurisicova A, Greenblatt EM, Casper RF. Preliminary experience with subcutaneous human ovarian cortex transplantation in the NOD-SCID mouse. Biol Reprod. 1999;60(6):1462-7. 7. Liu J, Van der Elst J, Van den Broecke R, Dhont M. Early massive follicle loss and apoptosis in heterotopically grafted newborn mouse ovaries. Hum Reprod. 2002;17:605-11.

8. Nisolle M, Casanas-Roux F, Qu J, Motta P, Donnez J. Histologic and ultrastructural evaluation of fresh and frozen-thawed human ovarian xenografts in nude mice. Fertil Steril. 2000;74(1):122-9.
9. Damous LL, Silva SM, Simões RS, Morello RJ, Carbonel AP, Simões MJ, Montero EF. Remote ischemic preconditioning on neovascularization and follicle viability on ovary autotransplantation in rats. Transplant Proc. 2008;40(3):861-4.

10. Gunasena KT, Villines PM, Critser ES, Critser JK. Live births after autologous transplant of cryopreserved mouse ovaries. Hum Reprod. 1997;12(1):101-6.

11. Corleta HE, Corleta O, Capp E, Edelweiss ME. Subcutaneous autologous ovarian transplantation in Wistar rats maintains hormone secretion. Fertil Steril. 1998;70(1):16-9.

12. Schubert B, Canis M, Darcha C, Artonne C, Smitz J, Grizard G. Follicular growth and estradiol follow-up after subcutaneous xenografting of fresh and cryopreserved human ovarian tissue. Fertil Steril. 2008;89(6):1787-94.

13. Choi JY, Lee BE, Lee EY, Yoon BK, Bae D, Choi DS. Cryopreservation of ovarian tissues temporarily suppresses the proliferation of granulose cells in mouse preantral follicles. Cryobilogy. 2008;56:36-42.

14. Nottola SA, Camboni A, Van Langendonckt A, Demylle D, Macchiarelli G, Dolmans MM, Martinez-Madrid B, Correr S, Donnez J. Cryopreservation and xenotransplantation of human ovarian tissue: an ultrastructural study. Fertil Steril. 2008;90(1):23-32.

15. Konstantinov IE, Arab S, Li J, Coles JG, Boscarino C, Mori A, Cukerman E, Dawood F, Cheung MM, Shimizu M, Liu PP, Redington AN. The remote ischemic preconditioning stimulus modifies gene expression in mouse myocardium. J Thorac Cardiovasc Surg. 2005;130(5):1326-32.

\section{Acknowledgment}

We thank the Fundação de Amparo à Pesquisa do Estado de São Paulo, FAPESP, which granted a PhD fellowship.

Conflict of interest: none Financial source: FAPESP (State of São Paulo Research Foundation) Proc. n. 2007/00107-9

\title{
Correspondence:
}

Edna Frasson de Souza Montero

Alameda Espada, 134 - Residencial 11

06540-395 Santana de Parnaiba - SP Brazil

Phone: (55 11)5549-7495

edna.montero@gmail.com

Received: March 11, 2009

Review: May 12, 2009

Accepted: June 15, 2009

\begin{abstract}
How to cite this article
Damous LL, Silva SM, Lopes RAM, Sakano CRSB, Simões MJ, Montero EFS. Study on the vaginal smear of rats submitted to autologous ovarian transplant: impact of remote ischemic preconditioning. Acta Cir Bras. [serial on the Internet] 2009 Sept-Oct;24(5). Available from URL: http://www.scielo.br/acb
\end{abstract}

*Color figures available from www.scielo.br/acb 